\title{
Evaluation of Field Techniques to Diagnose Early Subclinical Mastitis in Relation to Hygiene Score in a Buffalo Farm
}

\author{
Alyaa A. Saber ${ }^{1}$, Marwa A. Hassan ${ }^{2}$, Adel S. El Nabtiti ${ }^{3}$, Ahmed M. Hassan ${ }^{2}$ and Samira R. Mansour ${ }^{1 *}$ \\ ${ }^{1}$ Botany Department, Faculty of Science, Suez Canal University, Ismailia, Egypt \\ ${ }^{2}$ Department of Animal Hygiene, Zoonoses and Behaviour, Faculty of Veterinary Medicine, Suez Canal University, 41522, Ismailia, \\ Egypt \\ ${ }^{3}$ Department of Animal Wealth Development, Faculty of Veterinary Medicine, Suez Canal University, 41522, Ismailia, Egypt
}

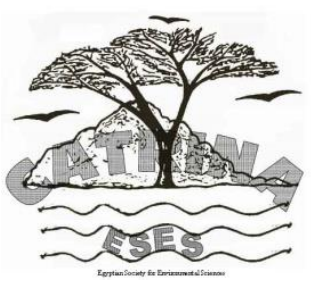

\begin{abstract}
This study was carried out to evaluate several diagnostic tests that could be used in early detection of subclinical mastitis in apparently healthy dairy buffaloes in a dairy farm, Ismailia, Egypt, in correlation to their hygienic status. In parallel, bacteriological examination of milk samples was carried out as a standard golden test. Recorded data showed that hygiene score was significantly influenced by seasonal variations at different sampling periods. California Mastitis Test (CMT) and electric conductivity (EC) measurements also displayed a significant variation between healthy buffaloes and those have subclinical mastitis along the year at different seasons. A significant correlation $(r=0.752)$ between CMT and EC measurements was verified and both tests showed the same prevalence of detecting subclinical mastitis among investigated samples. Bacteriological examination of milk samples was significantly different at sampling periods and was significantly correlated with EC measurements. A mixed infection of buffalo's udder was reported where Enterobacter spp. and coagulase-negative Staphylococcus (CNS) were the most common bacteria isolated from milk samples. Depending on the data obtained, the indirect screening tests such as CMT and EC could be used as reliable tests to monitor the udder health and the hygienic status in general. These ensure, on the spot, the high raw milk quality in the buffalo's farm. Therefore, this study suggests using these simple and fast tests for the early detection of the subclinical mastitis in lactating buffaloes.
\end{abstract}

Keywords: Subclinical mastitis, Buffalo, California mastitis test, EC, Hygiene score.

\section{INTRODUCTION}

Clinical and subclinical mastitis are the most economically damaging and zoonotic potential diseases for the dairy industry and consumers worldwide regardless of the animal species (Ojo et al., 2009). Clinical mastitis can be obviously detected by the inflammation of the mammary gland as a result of infection and multiplication of pathogenic microorganisms in this gland. In consequence, swelling, soreness in the udder, changes in milk composition and appearance will be recognized. However, subclinical mastitis does not lead to visible changes in milk or the udder, although it is considered as dangerous as clinical mastitis.

The changes occurred in the milk quality, resulted from subclinical mastitis, lead to huge economic loss as well as health problems that affect negatively on the public health (Hussain et al., 2012). Additionally, subclinical mastitis more frequently occurs, without early detection, it may lead to sequence development of clinical mastitis. In accordence to the severity, infected dose and duration, subclinical mastitis can be characterized into peracute, subacute, acute and chronic forms (Du Preez and Giesecke, 1994). Clinical and subclinical mastitis mostly occured due to bacterial, rickettsial and fungal infection as well as the physical injury of the udder during the act of milking process that exposed their tissue to infection from environment or from milking machines itself. Therefore, microbial mastitis could be categorized into two types: contagious pathogens like Staphylococcus aureus, Streptococcus species and Myc- coplasma, and environmental pathogens like Escherichia, Klebsiella sp. Enterobacteriaceae, yeasts and opportunistic microbes like coagulase-negative Staphylococcus (Blowey and Edmondson, 1995; Barkema et al., 2009). The contaminated milk is considered the major vehicle for the transmission of foodborne infection to the human and increase the risk of their illnesses (Sharma et al., 2011).

Risk factors that influence the incidence and motivation of mastitis, include host and environmental and management factors. Environmental factors are the mostly conspicuous risk factors that influence buffalo's susceptibility to mastitis. These factors include poor udder and milking hygiene; poorly designed facilities in housing system, dirty bedding or ground, poor ventilation and high humidity, stocking density and bedding materials. Poor diets and feeding materials, bad quality of milking machines are also among environmental risk factors that increase the incidence of mastitis to buffaloes.

Environmental mastitis is potentially caused by pathogens generally originated from the digestive tract such as "coliforms" or surroundings environments such as faeces, soil, bedding material and manure (Jones, 2006). Consequently, keeping environmental and management factors in the perfect state, a particularly hygienic status of animal and farm, are worthy and will assist to reduce the risk of animal mastitis. Although physical or bodily hygiene is an important indicator of welfare for dairy buffalos (Sant'Anna and Paranhos da Costa, 2011), there is a lack of information about the importance of 
individual variation in animal body hygiene, including the different part of the body, along the different season during the year. Therefore, finding quick and simple tests to detect early infection would be a treasure for manipulating the risk factors for high milk quality.

Variety of examinations, based on physical and chemical changes of milk, are available to regulate the presence or absence of subclinical mastitis. The majority of these tests include somatic cell count ( $\mathrm{SCC}$ ), $\mathrm{pH}$, California mastitis test (CMT), catalase test and electrical conductivity (EC) measurement. These indirect methods are primarily specified for the early incidence of subclinical mastitis in the form of inflammation in the udder (Joshi and Gokhale, 2006; Sharif et al., 2009). However, examination of microbial contaminant is still the golden standard test to be used for the diagnosis (Guha et al., 2010), but it needs time and lab facilities which are not assessable in most of the farms. Electrical conductivity (EC) of milk has been developed since the last decade (Sloth et al., 2003) to be used as a main indicator of mastitis. EC simply is the sum of the contribution of all the ions present in the certain solution, milk as in our case, thus its value will depend on the anions and cations concentrations. EC of milk from an infected animal affected by mastitis, showed an increase in its value due to the upsurge in sodium and chloride ion concentrations. In meantime, a decrease in potassium ion and lactose concentration was recorded (Ilie et al., 2010). The reliability of using milk electrical conductivity in the detection of subclinical mastitis was examined and gave useful information on udder health status (Galfi et al., 2015).

In Egypt, buffalo is an economically important livestock species for their milk, milk products, and meat. They also contribute to social and cultural aspects, mostly in agriculture activities. The Buffalo population in Egypt is in increase due to their milk quality, high fat and protein content, white colour, and flavour, which preferred by the Egyptian consumer. Buffaloes are considered the main source of milk in Egypt and contribute more than $70 \%$ of the annual milk production (AbuBakr, 2008). Buffaloes, owned by Egyptian small holders, generally live in traditional housing systems. These housing systems are lacking of facilities for testing healthy issues of living buffaloes, facing the deficiency of technical support and a shortage of pricing system for milk and feedstuffs (Radwan, 2016). These deficiencies lead to decrease in milk quality and inefficient milk production to meet the demand for industrial production and even the consumers. Therefore, the present study was carried out to elucidate the importance of using different indirect techniques under field conditions, in relation to hygienic scores, as a function of early detection of subclinical mastitis to prevent consequence of pathogen infections and milk loss.

\section{MATERIALS AND METHODS}

\section{Animals and facilities}

The study was carried out on a dairy buffalo's farm located in Ismailia province. Apparent healthy, lactating primiparous and multiparous buffaloes were subjected to milk sampling. These buffalos are housed in separate yards, each yard was provided with the manager, water trough located under sheds. The animals were left free in the yard which provided with the dirt floor and the buffaloes (ranged between 30 to 40 buffaloes during the investigation period) were manually milked twice a day in a separated a breast type parlor. The parlor is consisting of double raw, each raw consists of 29 stands, center or rear walk and one gutter. The floor of the parlor is cement and the wall made of brick with fine cement and provided with tap water for udder and utensils washing. The animals were fed silage and straw freely and the concentrate was given twice daily during milking.

\section{Samples and sampling procedure}

The herd was visited monthly for 4 seasons during the year 2014, to investigate the effect of the different seasons on the occurrence of subclinical mastitis. A total of 96 buffaloes were chosen to evaluate the hygiene score. CMT and EC measurements were also taken for 104 milk samples. A bacteriological examination was also carried out for the same milk samples to evaluate the ability of CMT and EC to be used for early detection of subclinical mastitis based on the total count of pathogenic bacterial isolated. Milk sampling size was 5 buffalos per subclinical mastitis (positive CMT) and 3 more buffaloes for normal one (negative CMT) which considered as control. This sample size was consistent for each month.

Milk samples were collected after teat cleaning by removing any possible dirt and washed with tap water, and then the teat end was dried out and swabbed with $70 \%$ ethyl alcohol-soaked cotton. The milking streams were collected and subjected to CMT test. However, for EC measurement, about $50 \mathrm{ml}$ from each quarter were collected and measured using EC electrode. For bacteriological examination, approximately $15 \mathrm{ml}$ of milk were collected aseptically into sterile bottles and were directly transported to the laboratory in an ice cooled box and immediately subjected to bacterial examination on specific media and incubated at $37^{\circ} \mathrm{C}$. Colonies appeared, within $48 \mathrm{hrs}$, were counted and then identified following the chart of Bergey's Manual of Determinative Bacteriology (Bergey and Holt, 1993).

\section{Hygiene score}

The hygiene status of the lactating buffaloes, at our sampling site, was evaluated and scored throughout the sampling periods. Based on visual hygiene score, four point scale system was followed as described by Schreiner and Ruegg (2003) where udder (U), abdomen (A), flanks (F) and legs (L) of each buffalo were scored. Score 1 , was referred to very clean skin while score 4 , referred to dirty skin in which the skin was entirely covered with dirt. Composite hygiene score (CS) was calculated in which the hygiene of scored four areas were combined following the method of Sant' Anna and Paranhos da Costa (2011). The scaled scores; Very Clean animal (VC), in which one area at least of the body had score 1 and the remaining areas had score 2; Clean (C) referred to 2 areas of the body had score 2 and none scored 4; Dirty (D), 2 or more areas had a score of 3, 
with a maximum of one area with a score 2 and two areas with a score of 4 , and Very Dirty (VD) referred to 3 or more areas of the skin had score 4 .

\section{California Mastitis Test (CMT)}

The California mastitis test was conducted to diagnose the presence of subclinical mastitis as a function of somatic cell count of milk. CMT was carried out according to the procedure given by (Quinn et al., 1994), where the four quarters of the individual buffalo were tested separately.

\section{Electrical conductivity (EC)}

Electrical conductivity was used for diagnosing bovine mastitis as recommended by (Nielen et al., 1992). EC $\mathrm{mS} / \mathrm{cm}$ of milk samples was determined by means of conductivity meter (Hanna Dist. 4 HI98304 instrument, Mauritius, USA).

\section{Statistical analysis}

Data obtained were statistically analysed to detect the significant difference among different measured parameters using ANOVA test, at $\mathrm{p}>0.05$ and chi-square (X2 test). Statistical analysis was carried out using SPSS, version 16 computer programs (Inc., 1989-2010). Correlation coefficient has been implemented to measure the strength of association between measured parameters. Sensitivity and specificity with ROC curve also was analysed using XL stat software program (2015 Addin soft SARL, Paris).

\section{RESULTS}

Data in table (1) revealed that the hygiene scores of buff-aloes, as a composite hygiene score (CS), were very clean (VC) which represented by $24.21 \%$ and clean (C) was represented by $57.89 \%$. The score clean was collectively recorded the highest percentage value (82\%) among tested sampled buffaloes. However, dirty score (D) and very dirty (VD) were represented by $16.84 \%$ and $1.05 \%$, respectively. Data recorded in table 2 showed that there was a significant $(\mathrm{p} \leq 0.01)$ positive correlation between hygiene score and different seasons of collected samples. In meantime, the hygiene score was negatively correlated with a number of the isolated pathogen.

Evaluation of field tests, for early detection of subclinical mastitis, was conducted in form of CMT and EC of milk measurements in compared to the number of pathogenic isolates. As analysed by measuring accuracy, sensitivity and specificity, a detection of cut-off point was recorded. Table (3) and figure (1) showed that grade Trace of CMT was nearly similar values of sensitivity and specificity (0.660 and 0.614 , respectively). However, positive and negative predictive values (PPV and NPV) were 0.631 and 0.643 , respectively. So, this grade could be a cut-off point for CMT for detection of subclinical mastitis, whereas, grades $(+)$ and $(++)$ showed strong reaction compared to trace grad and considered positive for subclinical mastitis. Relative frequency of pathogenic organisms isolated from milk samples (Fig. 2), displayed the occurrence of the highest prevalent single bacteria that causing subclinical mastitis. This bacteria was identified to be coagulase negative Staphylococci (CNS) and represented by $7.38 \%$, followed by Enterobacter spp. with prevalence rates of $4.7 \%$. Meanwhile, mixed infection, more than 2 different microorganisms, showed the highest frequency with prevalence rates of $71.812 \%$. Results recorded in table (3) and figure (3) revealed different accuracy, sensitivity, and specificity of different EC ranges, whereas, ranges of 2.2-3.95 $\mathrm{mS} / \mathrm{cm}$ showed high sensitivity $(0.92$ 8) with NPV of 0.817 . This means that samples lied within this range will be negative, a range of (4-4.9) $\mathrm{mS} / \mathrm{cm}$ showed questionable results which could be suspected to be positive or negative with the similar chance of sensitivity and specificity (0.642 and 0.563$)$. However, PPV and NPV recorded 0.597 and 0.612 with an accuracy of 0.599 . On the other hand, EC ranged from 5 to $5.8 \mathrm{mS} / \mathrm{cm}$ could be considered as cut-off point for detection of subclinical mastitis with a higher specificity of 0.846 and accuracy of 0.64 . Therefore, EC $>5.8 \mathrm{mS} / \mathrm{cm}$ considered a positive detection of early subclinical mastitis. This suggestion is confirmed by the high specificity with PPV that recorded with EC > $6 \mathrm{mS} / \mathrm{cm}$.

Table (1): Hygiene score of studied buffaloes and their proportion categories.

\begin{tabular}{|c|c|c|c|c|c|c|c|}
\hline \multicolumn{2}{|c|}{ Hygiene score } & \multirow{2}{*}{$\begin{array}{c}\text { Udder } \\
74\end{array}$} & \multirow{2}{*}{$\begin{array}{c}\text { Abdomen } \\
20\end{array}$} & \multirow{2}{*}{$\begin{array}{l}\text { Flank } \\
25\end{array}$} & \multirow{2}{*}{$\begin{array}{c}\text { Leg } \\
6\end{array}$} & \multicolumn{2}{|c|}{ **Composite score } \\
\hline$*$ & No. & & & & & \multirow{2}{*}{ VC } & 23 \\
\hline 1 & Percentage & 77.08 & 20.83 & 26.04 & 6.25 & & 24.21 \\
\hline$*$ & No. & 21 & 61 & 69 & 33 & \multirow{2}{*}{$\mathrm{C}$} & 55 \\
\hline 2 & Percentage & 21.88 & 63.54 & 71.88 & 34.38 & & 57.89 \\
\hline$*$ & No. & 1 & 13 & 2 & 53 & \multirow{2}{*}{$\mathrm{D}$} & 16 \\
\hline 3 & Percentage & 1.04 & 13.54 & 2.08 & 55.21 & & 16.84 \\
\hline$*$ & No. & 0 & 2 & 0 & 4 & \multirow{2}{*}{ VD } & 1 \\
\hline 4 & Percentage & 0 & 2.08 & 0 & 4.17 & & 1.05 \\
\hline
\end{tabular}




\section{Evaluation of field techniques to diagnose early subclinical mastitis}

Table (2): Correlation coefficient between pathogenic isolates, CMT and EC during different seasons of sampling.

\begin{tabular}{lccccc}
\hline \hline & Season & Pathogen & CMT & EC & Hygiene score \\
\hline Season & 1 & $-0.319^{* *}$ & $-0.040-$ & $-0.006-$ & $0.243^{*}$ \\
Pathogen & & 1 & 0.071 & 0.136 & $-0.090-$ \\
CMT & & & 1 & $0.752^{* *}$ & $-0.223-$ \\
EC & & & 1 & $-0.070-$ \\
Hygiene score & \multicolumn{7}{c}{1} \\
\hline \hline
\end{tabular}

Table (3): Accuracy and cut-off value of California mastitis test (CMT) and electrical conductivity (EC) for the detection of subclinical mastitis.

\begin{tabular}{|c|c|c|c|c|c|c|c|c|c|c|c|}
\hline \multicolumn{2}{|c|}{ Diagnostic tests } & Sensitivity & Specificity & PPV & NPV & $\mathbf{T P}$ & $\mathbf{T N}$ & $\mathbf{F P}$ & $\mathbf{F N}$ & $\begin{array}{l}\text { Sensitivity } \\
+ \text { Specificity }\end{array}$ & Accuracy \\
\hline \multirow{4}{*}{ CMT } & 0 & 1 & 0 & 0.5 & & 47 & 0 & 57 & 0 & 1 & 0.452 \\
\hline & Trace & 0.66 & 0.614 & 0.631 & 0.643 & 31 & 35 & 22 & 16 & 1.274 & 0.635 \\
\hline & $1(+)$ & 0.404 & 0.667 & 0.548 & 0.528 & 19 & 38 & 19 & 28 & 1.071 & 0.548 \\
\hline & $2(++)$ & 0.234 & 0.912 & 0.727 & 0.544 & 11 & 52 & 5 & 36 & 1.146 & 0.606 \\
\hline \multirow{5}{*}{$\begin{array}{l}\mathrm{EC} \\
(\mathrm{mS} / \mathrm{cm})\end{array}$} & $2.2-3.95$ & 0.928 & 0.2 & 0.542 & 0.817 & 43 & 11 & 46 & 3 & 1.128 & 0.529 \\
\hline & $4-4.9$ & 0.642 & 0.563 & 0.597 & 0.619 & 30 & 32 & 25 & 17 & 1.204 & 0.599 \\
\hline & $5-5.8$ & 0.391 & 0.846 & 0.719 & 0.582 & 18 & 48 & 9 & 29 & 1.237 & 0.64 \\
\hline & $6-6.6$ & 0.243 & 0.912 & 0.736 & 0.547 & 11 & 52 & 5 & 36 & 1.155 & 0.61 \\
\hline & $\geq 7(7-10)$ & 0.103 & 0.974 & 0.844 & 0.521 & 5 & 56 & 2 & 42 & 1.077 & 0.58 \\
\hline
\end{tabular}

Sensitivity corresponds to the rate of positive cases that are well diagnosed by the test ; Specificity corresponds to the rate of negatives cases that are well diagnosed by the test ; $\mathrm{TP}=$ True positive for isolation of pathogen with $\mathrm{CMT}$ or $\mathrm{EC}$. ; FP=False positive which is positive for CMT or EC and negative for isolation of pathogen.;TN= True negative for isolation of pathogen with CMT or EC.; FN= False negative which is negative for CMT or EC and positive for isolation of pathogen.

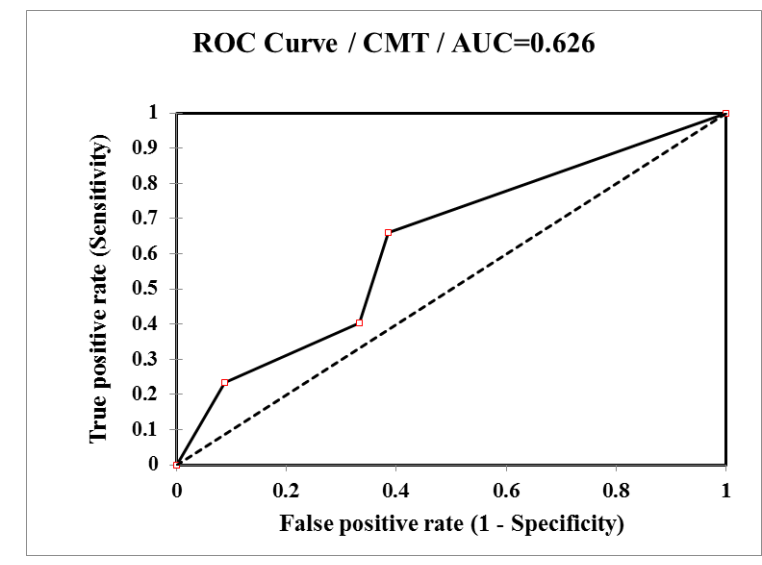

Figure (1): ROC curve of diagnostic ability of CMT for subclinical mastitis based on isolation of pathogens from milk samples.
In general, EC showed higher sensitivity than CMT for detection of subclinical mastitis, EC showed higher false positive rate than CMT. In addition, both tests showed the same prevalence of detecting subclinical mastitis (0.452) (data not shown). Meanwhile, area under the curve (AUC), illustrated in figures (1 and 3), recorded the ability for detection of subclinical mastitis that almost near rates with higher EC value 0.666 as compared to CMT (0.626). This result could be supported by the correlation between EC and pathogen isolation which showed higher correlation value $(r=0.136)$ than those with $\mathrm{CMT}(\mathrm{r}=0.071)$ (Table 2). The recorded value of EC ranged from 4 to $4.9 \mathrm{mS} / \mathrm{cm}$ could be considered as cut off point. Therefore, the value of $\mathrm{EC}>4.9 \mathrm{mS} / \mathrm{cm}$ represents an alarm for subclinical mastitis with high sensitivity and specificity along with higher value of true positive and negative cases (1.6545) with accuracy.

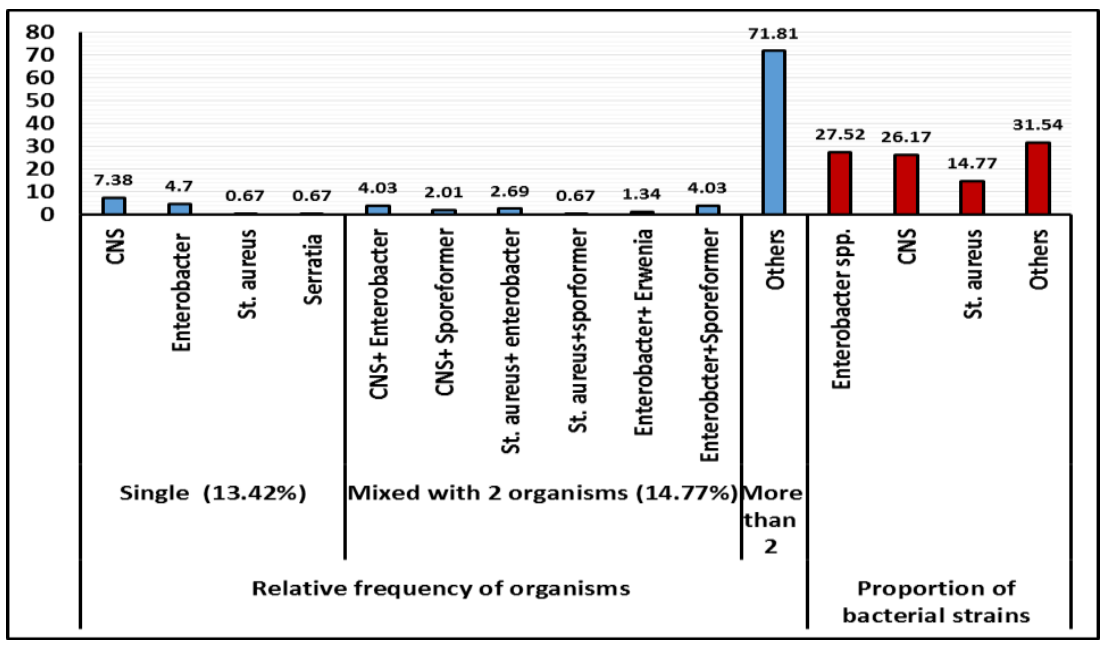

Figure (2): Relative frequency of isolated organisms and their proportion during milk sampling. 
Table (4): Accuracy and cut-off value of milk Electrical Conductivity for the detection of subclinical mastitis, at the quarter level, based on California mastitis test (CMT).

\begin{tabular}{ccccccccccc}
\hline \hline $\begin{array}{c}\text { EC } \\
(\mathbf{m S} / \mathbf{c m})\end{array}$ & Sensitivity & Specificity & PPV & NPV & TP & TN & FP & FN $\begin{array}{c}\text { Sensitivity } \\
+ \\
\text { Specificity }\end{array}$ & Accuracy \\
\hline $2.2-3.95$ & 0.999 & 0.288 & 0.598 & 0.998 & 53 & 15 & 36 & 0 & 1.287 & 0.650 \\
$4-4.9$ & 0.850 & 0.804 & 0.814 & 0.868 & 45 & 41 & 10 & 8 & 1.654 & 0.827 \\
$5-5.8$ & 0.472 & 0.957 & 0.924 & 0.644 & 25 & 49 & 2.2 & 28 & 1.429 & 0.710 \\
$6-6.6$ & 0.309 & 1 & 1 & 0.592 & 16 & 51 & 0 & 37 & 1.309 & 0.648 \\
$7-10$ & 0.099 & 1 & 1 & 0.527 & 5 & 51 & 0 & 48 & 1.099 & 0.541 \\
\hline \hline
\end{tabular}

Sensitivity is the proportion of true positives subclinical mastitis that are detected by EC method based on CMT;

Specificity is the proportion of true negatives that are detected by EC method based on CMT.

$\mathrm{PPV}=$ Positive predictive value is the proportion of milk samples with positive EC test results which have subclinical mastitis based on CMT.

$\mathrm{NPV}=$ Negative predictive value is the proportion of milk samples with negative EC test results which do not have subclinical mastitis based on CMT.

$\mathrm{TP}=$ True positive milk samples using $\mathrm{EC}$ and $\mathrm{CMT}$

$\mathrm{TN}=$ True negative milk using EC and CMT

$\mathrm{FP}=$ False positive milk samples which show positive $\mathrm{EC}$ while it is negative for $\mathrm{CMT}$

$\mathrm{FN}=$ False negative milk samples which show negative EC while it is positive for CMT

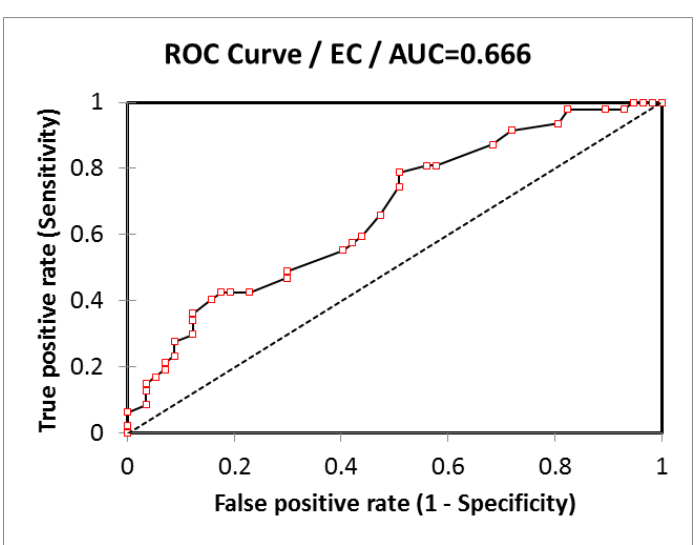

Figure (3): ROC curve of diagnostic ability of EC (mS/cm), for subclinical mastitis, in correlation to isolated pathogens from milk samples

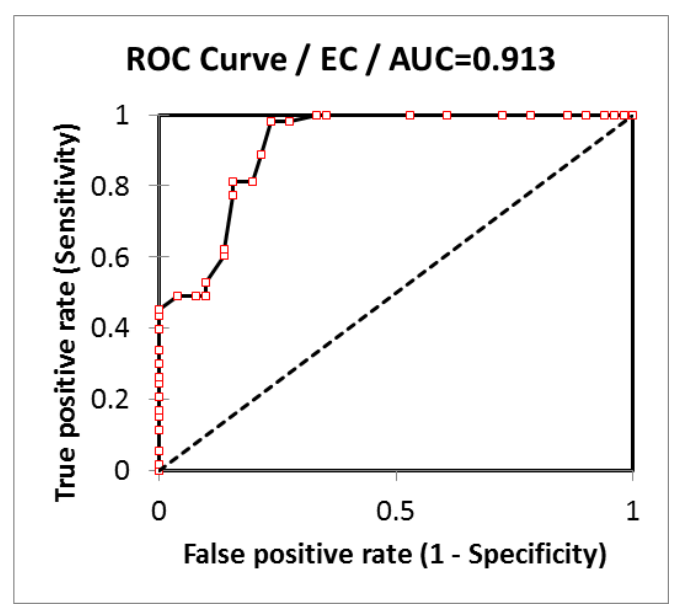

Figure (4): ROC curve of diagnostic ability of EC (mS/cm), for subclinical mastitis, in correlation to CMT results.

of 0.8275 (Table 4). In general, compatibility between using EC and CMT reached high level with AUC (area under the curve) of 0.913 (Fig. 4) which increases subclinical mastitis diagnostic ability of EC based on CMT

\section{DISCUSSION}

It is clear from the reported results that environmental pathogens were the predominant microorganisms that causing subclinical mastitis including Enterobacter spp. and coagulase negative Staphylococci (CNS).They repr- esented the most prevalent single pathogen isolated from infected milk. This could be explained by that the environment surrounding dairy animals is the primary source of "coliform" infection which occurred during the time of milking and before the first parturition in heifers (Pankey, 1989). Furthermore, contamination of mammary gland and the surrounding environment with animal dung leading to higher proportion of Enterobacteriaceae (Mergana, 2012). CNS is considered as important minor mastitis pathogens in Egyptian dairy animals, however, they can cause severe economic losses of milk yield. Therefore, keeping environmental hazard far by monitoring the hygienic status of animals and the farm is important. This can be done by measuring the indirect fact and easy indicator methods and continuous cleaning of parlor flour and buffaloes bodies (El-Jakee et al., 2013). Work done by Hashemi et al. (2011) confirms our results and stated that regular screening of udder health status, housing and milking parlor sanitation, adequate milking practice with dry buffalo management are essential for achieving an effective control program for contiguous mastitis.

An assessment of animal and environment hygiene, have been developed using hygiene scoring system (Ward et al., 2002 and Reneau et al., 2003), and from our data, reported in this study, revealed that average udder hygiene score showed higher hygiene than leg and flank. Our results are in agreement with Schreiner and Ruegg (2003), who reported that proportion of leg hygiene score was categorized as dirty more than a proportion of udder hygiene score. These results could be explained by the fact that this anatomical region of the Buffaloes' body is more exposed to environmental dirt, especially when they use paths with accumulated mud (Hughes, 2001; Sant'Anna and Paranhos da Costa, 2011). Furthermore, composite score showed the highest frequency of clean score (C) and the lowest one for a very dirty score (VD). Our results are in consistency with study done by Sandrucci et al. (2014).

Different methods for detecting the subclinical mastitis, such as the California mastitis test (CMT), SCC, some biochemical methods, the presence of pathogens in the milk, and electrical conductivity (EC) have been used worldwide in bovines (Pradieé et al., 2012). CMT as compared to bacterial growth revealed that score Trace could be suspected subclinical mastitis 
which need confirmation by bacterial culture to exclude false positive and detect false negative and these results are in good agreement with other studies which have shown that grade Trace of CMT showed high specificity $(66.7 \%)$ and specificity $(54.8 \%)$ (Ruegg and Reinemann, 2002).

The sensitivity of the positive CMT results in the present study was $60.7 \%$. CMT +1 score can be recommended as a threshold value for detecting subclinical mastitis (Ergün et al., 2009). Furthermore, Las Heras et al. (1999) reported that score +1 is the best CMT score for indicating subclinical mastitis in sheep. On the other hand, higher specificity was also observed in a score of ++ CMT. The presence of positive interactions does not necessarily indicate the presence of mastitis (Roukbi et al., 2015). The bacterial toxins that reach the blood-stream may lead to massive destroying of white blood cells without being associated with a positive result in CMT (Wagner et al., 2007).

For EC assessment of milk for early detection of subclinical mastitis, based on the isolated pathogens, our results showed that EC ranges of 2.2-3.95 mS/cm had high sensitivity with a negative predictive value which means that samples laid within this range will be negative for subclinical mastitis. These results might be supported by the data recorded by Dhakal et al. (2008) who reported the sensitivity and specificity for diagnosing submastitis in buffalo by EC score. They also recorded that cut-off value was $3.7 \mathrm{mS} / \mathrm{cm}$ with NPV of 0.955. Generally, EC value in normal buffalo milk was $3.7 \mathrm{mS} / \mathrm{cm}$, and the EC of normal cow milk was approximately $4.6 \mathrm{mS} / \mathrm{cm}$ (Neville and Jensen, 1995). Relatively lower EC values in buffalo milk may be due to an increase in fat content, about $7.5 \%$, as milk fat concentration is inversely correlated with EC (Nielen et al., 1992). On the other hand, EC ranged between 4-4.9 $\mathrm{mS} / \mathrm{cm}$ represented almost near values of PPV and NPV. So this range could be considered the alarm for subclinical mastitis which could be aided and confirmed by bacterial isolation. These results are in agreement with Dhakal et al. (2008) who suggests that an absolute EC score $>4$ considered indicative of subclinical mastitis, while higher specificity was observed when EC $\geq 5.8 \mathrm{mS} / \mathrm{cm}$ which considered as cut-off point. In addition, our finding could be strengthened by records of Nielen et al. (1992) and Kaşikçi et al. (2012) who reported that EC of normal milk appears to be between 4.0 and $5.5 \mathrm{mS} / \mathrm{cm}$ at $25^{\circ} \mathrm{C}$.

Cut-off point for EC in comparison to CMT could be $>4.9 \mathrm{mS} / \mathrm{cm}$ which referred to suspect mastitis and this results in contrast with records obtained by Roukbi et al. (2015) who reported that the values of EC in goat milk for negative suspected and positive $(+1)$ CMT milk samples were $3.93 \pm 0.64,4.47 \pm 0.61$ and $4.68 \pm 0.72$, respectively. They also reported the values of EC for $(+++)$ CMT was $6.56 \pm 0.85$. The presence of subclinical mastitis could be supported by the CMT positive results, furthermore, the increase in SCC resulted in an increase of the EC (Kaşikçi et al., 2012). In conclusion, this study revealed that the hygienic status of buffalo's body is important particularly udder hygiene for preventing mastitis. The most prevalent microorganism isolated from mastitis milk samples was environmentally origin such as Enterobacter spp. and CNS. It was cleared that average udder hygiene score showed higher hygiene than leg and flank with higher percentages of the Composite score is clean. The indirect screening tests of mastitis such as CMT and EC seem to be more suitable for selecting animals with subclinical mastitis. Compatibility between using EC and CMT reached a high level with strong positive significant correlation $(\mathrm{p} \leq 0.01)$.

In general, EC showed higher sensitivity than CMT for detection of subclinical mastitis, EC showed higher false positive rate than CMT. In addition, both tests showed the same prevalence of detecting subclinical mastitis. Additionally, EC measurement as the indirect technique, could be used as it is quick, cheap and easy test to be applied. This method could be recommended for in spot detection of early mastitis.

\section{REFERENCES}

ABOU-BAKR, S. 2008. Estimation of breeding values of total milk yield of Egyptian buffalo under differrent production systems (Doctoral dissertation, Cairo University).

BARKEMA, H. W., M. J. GREEN, A. J. BRADLEY, AND R. N. ZADOKS. 2009. Invited review: The role of contagious disease in udder health. J. Dairy Sci., vol. 92, p. 4717- 4729.

BERGEY, D. AND G. HOLT. 1993. Bergey's Manual of Determinative Microbiology $9^{\text {th }}$, published by Lippincott, Williams, and Wilkins.

BLOWEY, R., AND P. EDMONDSON. 1995. Mastitis control in dairy herds, an illustrated and practical guide, fanning Press Books, U.K

DHAKAL, B. K., R. R. KULESUS, AND M. A. MULVEY. 2008. Mechanisms and consequences of bladder cell invasion by uropathogenic Escherichia coli. Eur J Clin Invest.; 38(2): 2-11.

DU PREEZ, J. H. AND W. H. GIESECKE. 1994. Mastitis. In: Coetzer J.A.W., Thomson G.R. Infectious Diseases of Livestock. Oxford University Press Edit. 2:1564-1595.

EL-JAKEE, J. K., N. E. AREF, A. A. GOMA, M. D. EL-HARIRI, H. M. GALAL, S. A. OMAR, AND A. SAMIR. 2013. Emerging of coagulase negative staphylococci as a cause of mastitis in dairy animals: An environmental hazard. International Journal of Veterinary Science and Medicine.

ERGÜN, Y., Ö. ASLANTAŞ, G. DOĞRUER, E. KIRE-ÇCI, M. K. SARIBAY, C. T. ATEŞ, A. ÜLKÜ, AND C. DEMIR. 2009. Prevalence and etiology of subclinical mastitis in Awassi dairy ewes in southern Turkey. Turk. J. Vet. Anim. Sci. 33(6): 477-483.

GALFI A., M. RADINOVIĆ, D. MILANOV, S. BOBOŠ, M. PAJIĆ, S. SAVIĆ, I. DAVIDOV. 2015. Electrical Conductivity Of Milk And Bacteriological Findings In Cows With Subclinical Mastitis. Biotechnology in Animal Hus-bandry 31 (4), p 533541. 
GUHA, A., S. GERA, AND A. SHARMA. 2010. Assessment of chemical and electrolyte profiles as an indicator of subclinical mastitis in riverine buffalo (Bubalus bubalis). Haryana vet, 49: 19-21.

HASHEMI, M., M. KAFI, AND M. SAFDARIAN. 2011. The prevalence of clinical and subclinical mastitis in dairy cows in the central region of Fars province, south of Iran. Iranian Journal of Veterinary Research, Shiraz University, Vol. 12, No. 3, Ser. No. 36.

HUGHES, J. 2001. A system for assessing cow cleanliness. In Pract. 23: 517-524.

HUSSAIN, R., M. T. JAVED, AND A. KHAN. 2012. Changes in some biochemical parameters and somatic cell counts in the milk of buffalo and cattle suffering from mastitis. Pak Vet J, 32(3): 418-421.

ILIE, L. I., L. TUDOR, A. M. GALIŞ. 2010. the Electrical Conductivity of Cattle Milk and the Possibility of Mastitis Diagnosis In Romania. Lucrări Ştiinłifice Medicină Veterinară VOL. XLIII (2), Timisoara.

JONES, G. M. 2006. Understanding the basics of mastitis. Virginia Cooperative Extension, Publication No. 404-233, Virginia State University, USA, 1-7.

JOSHI, S. AND S. GOKHALE. 2006. Status of mastitis as an emerging disease in improved and periurban dairy farms in India. Ann NY Acad Sci 1081: 74-83.

KAŞIKÇI, G., Ö. ÇETIN, E. B. BINGÖL, AND C. GÜNDÜ. 2012. Relations between electrical conductivity, somatic cell count, California mastitis test and some quality parameters in the diagnosis of subclinical mastitis in dairy cows. Turk. J. Vet. Anim. Sci. 36(1): 49-55.

Las Heras, A., L. Dominguez, and J. F. F ernandezGarayzabal. 1999. Prevalence and aetiology of subclinical mastitis in dairy ewes of the Madrid region. Small Rumin. Res. 32: 21-29

MERANGA, M. E. 2012. Study on Prevalence of Mastitis and Associated Risk Factors with Isolation and Antimicrobial Susceptibility of Major Pat hogs In Algae State Dairy Farm, ETHIOPIA.

NEVILLE, M. C., AND R. G. JENSEN. 1995. The physical properties of human and bovine milk. In Handbook of Milk Composition. R.G. Jensen, ed. (Academic Press, San Diego) pp. 81-85.

NIELEN, M., H. DELUYKER, Y.H. SCHUKKEN, AND A. BRAND. 1992. Electrical conductivity of milk: measurement, modifiers, and meta-analysis of mastitis detection performance. J. Dairy Sci., 1992; 75: 606-614.

OJO, O.E., M. A. OYEKUNLE, A. O. OGUNLEYE, AND E. B. OTESILE. 2009. Escherichia coli, O157: $\mathrm{H} 7$ in food animals in part of South-Western Nigeria. Prevalence and in vitro antimicrobial susceptibility. Trop. Vet. 26(3): 23-30.

PANKEY, J. W. 1989. Hygiene at milking time in the prevention of bovine mastitis. Br. Vet. J., 145: 401409.
PRADIEÉ, J., C. R. MORAES, M. GONÇALVES, M. S. VILANOVA, G. F. CORRÊA, O. G. RLAUZ, M. T. M. OSÓRIO, AND V. SCHMIDT. 2012. Somatic Cell Count and California Mastitis Test as a Diagnostic Tool for Subclinical Mastitis in Ewes. Acta Scientiae Veterinariae. 40(2): 1038.

QUINN, P. J., M. E. CARTER, B. K. MARKEY, AND G. R. CARTER. 1994. Clinical veterinary microbial. Wolfe, Baltmore. pp. 327-344.

RADWAN, M. A. A. 2016. Characterization of milk and veal production chains of. Buffalo under crop live-stock production system in Egypt. Ph.D. Thesis.

RENEAU, J. K., A. J. SEYKORA, AND B. J. HEINS. 2003. Relationship of cow hygiene scores and SCC. In: Proc. Natl. Mast. Coun. Madison, WI. 2003; p. 362-363.

ROUKBI, M., A. N. OMAR, Z. SALAM, AND K. DIBEH. 2015. Investigation of subclinical mastitis cases in GCSAR Damascus goats from Humeimeh research station. Net Journal of Agricultural Science Vol. 3(1), pp. 5-13, January ISSN: 2315-9766.

RUEGG, P. L., AND D. J. REINEMANN. 2002. Milk quality and mastitis tests. Bovine Pract. 36: 41-54.

SANDRUCCI, A., L. BAVA, M. ZUCALI, AND A. TAMBURINI. 2014. Management factors and cow traits influencing milk somatic cell counts and teat hyperkeratosis during different seasons, Revista Brasileira de Zootecnia. ISSN 1806-9290.

SANT'ANNA, A. C. AND M. J. R. PARANHOS DA COSTA. 2011. The relationship between dairy cow hygiene and somatic cell count in milk. J. Dairy Sci. 94: 3835-3844.

SCHREINER, D. A., AND P. L. RUEGG. 2003. Relationship between udder and leg hygiene scores and subclinical mastitis. J.Dairy.Sci. 86: 3460-3465.

SHARIF, A., M. UMER AND G. MUHAMMAD. 2009. Mastitis control in dairy production. J. Agric. Soc. Sci. 5:102-105.

SHARMA, N., N. K. SINGH, AND M. S. BHADWA, 2011. Relationship of Somatic Cell Count and Mastitis: An Overview. Asian-Aust. J. Anim. Sci. Vol. 24, No. 3: 429-438.

SLOTH, K.H.M.N., N. C. FRIGGENS, P. LOVENDAHL, AND P.H. ERSEN, J. JENSEN, AND K.L. INGVARTSEN. 2003. Potential for improving description of bovine udder health status by combined analysis of milk measures, J. Dairy Sci., 2003, 86: 1221-1232.

WAGNER, S. A., D. E. JONER, AND M. D. APLEY. 2007. Effect of endotoxin mastitis on epithelial cell numbers in the milk of dairy cows. Am J Vet Res, 70: 796-799.

WARD, W. R., J.W.HUGHES, W. B. FAULL, P. J CRIPPS, J. P. SUTHERL AND J. E. SUTHERST. 2002. Observational study of temperature, moisture, $\mathrm{pH}$ and bacteria in straw bedding, and faecal consistency, cleanliness and mastitis in cows in four dairy herds. Veterinary Record 151: 199-206. 


\section{تقييم التقتيات الميدانية لتشخيص التهاب الضرع تحت الإكلينيكي المبكر فيما يتعلق بنتيجة النظافة في مزرعة الجاموس}

\section{علياء صابر' ، مروه حسن' ، عادل التبطيتي '، احمد حسن '، سميزه منصور'}

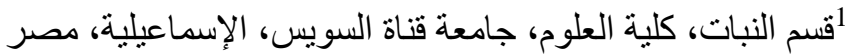

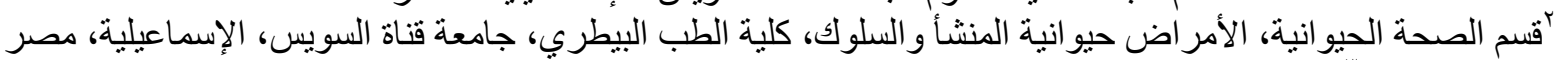

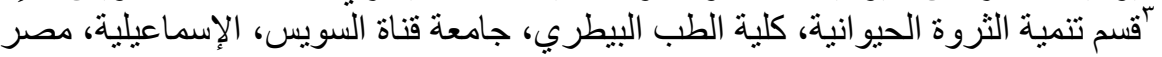

\section{الملخص العربي}

أجريت هذه الدراسة لتقييم العديد من الاختبارات الحقلية التي يمكن استخدامها في الكثف المبكر عن التهاب الضرع تحت السريري في الجاموس الحلاب في مزر عة ألبان، الإسماعيلية، مصر، هذا بالاضافة الى تقييم مستوى نظافة حيوانات الحلب. ولهذا تم تقييم الاختبار ات الحقلية السريعة اللازمة للتعرف على التهاب الضرع تحت السريري اثناء الحلب و تحديد مدى كفاءتها احصائيا بالمقارنة للعزل البكتيري الذي يعتبر العنصر الاساسي للتعرف علي حدوث المرض. وقد أظهرت النتائج أن درجة النظافة قد تأثرت بشكل كبير بالتغير ات الموسمية المختلفة والتي قد تلعب دور كبير فى الاسراع في حدوث المرض وخطورته. كما أوضح اختبار الكاليفورنيا (CMT) و اختبار قيمة التوصيل الكهربى (EC) تفاونا واضحا بين الجاموس الصحي مظهريا و الذين r = لديهم التهاب الضرع تحت السريري على طول السنة في المواسم المختلفة. كما اثبتت الدراسة وجودعلاقة ارتباط قوية 0.752) بين قياسات CMT و EC. كما أظهر كل من الاختبارين نفس الانتشار بالنسبة لمرض التهاب الضرع تحت السريري. كما اوضحت الدراسة ان العزل البكتيري لعينات الحليب لنفس الجاموس الحلاب، محل الدراسة، مختلفًا بشكل كبير في فترات أخذ العينات فى المواسم المختلفة واظهرارتبطًا معنويا كبير مع قياسات EC. كما أظهرت النتائج ان وجود مجموعة مختلطة من ميكروب هم: Enterobacter والخلايا العنقودية سالبة التخثر Coagulase negative staphylococci انتشار ا وشيو عًا للبكتريا المعزولة من عينات اللبن. واعتمادا على التحاليل الاحصائية للبيانات التي تم الحصول عليها وقوة دلالتها للاختبار ات محل الدر اسة، يمكن استخدام اختبار ات الفحص غير المباشرة مثل CMT و EC كاختبار ات موثوقة لمراقبة صحة الضرع و الوضع الصحي بشكل عام. وبهذا يمكن الاكتشاف المبكر لمرض التهاب الضرع تحت السريري و معالجته بشكل سريع وبهذا يضمن الجودة العالية للالبان الخام في اي مزرعة للجاموس. ولذلك، تقترح هذه الدراسة استخدام هذه الاختبارات البسيطة و السريعة للكثف المبكر عن التهاب الضرع تحت السريري في الجاموس الحلاب لما لها قوة فى اكتشاف المرض. 